Article

\title{
Open-Mindedness Culture, Knowledge-Sharing, Financial Performance, and Industry 4.0 in SMEs
}

\author{
Anna Michna * and Roman Kmieciak (1) \\ Faculty of Organization and Management, Silesian University of Technology, 41-800 Zabrze, Poland; \\ roman.kmieciak@polsl.pl \\ * Correspondence: anna.michna@polsl.pl
}

Received: 27 September 2020; Accepted: 28 October 2020; Published: 30 October 2020

check for updates

\begin{abstract}
Due to limited resources, the implementation of Industry 4.0 solutions is a big challenge in small- and medium-sized enterprises (SMEs). Therefore, it is important to identify the factors that facilitate such implementation. However, empirical research in this area is insufficient. The purpose of this article is to investigate whether open-mindedness culture, knowledge-sharing, and financial performance have a significant impact on willingness to implement Industry 4.0 in SMEs. To achieve the purpose of the article, quantitative research was conducted. Data from 562 Polish manufacturing SMEs were collected and analyses were performed using partial least squares path modeling (PLS-PM). The study results reveal that open-mindedness culture has both a direct and indirect (through knowledge sharing) impact on willingness to implement Industry 4.0 in SMEs. Results suggest that in terms of micro-enterprises, open-mindedness is more important and knowledge-sharing is less important for willingness to implement Industry 4.0 than in larger enterprises. Moreover, regardless of the company size, financial performance is positively related to willingness to implement Industry 4.0. The research results provide SME managers with guidelines on what activities within the company should be strengthened if the goal of the company is to implement Industry 4.0 solutions.
\end{abstract}

Keywords: open-mindedness culture; knowledge sharing; financial performance; Industry 4.0; SMEs

\section{Introduction}

For a decade, the concept of Industry 4.0 has been arousing more and more research interest. Industry 4.0 is identified as the expected fourth industrial revolution and perceived as "a technology-driven paradigm shift of the manufacturing industry that will digitally integrate production networks both horizontally and vertically" [1] (p. 3952). This concept is based on two main technologies, Cyber-Physical Systems (CPS) and the Internet of Things [2]. These technologies are intended to integrate machines, devices, production and logistics systems, and users with the use of information and communication technologies [3]. The implementation of the Industry 4.0 concept in the company is to be a response to changes in the company's environment, such as globalization, strong competition, and market volatility. Industry 4.0 is aimed at improving the company's competitive position, ensuring flexibility in production, the ability to respond to changing customer demands and individual needs $[4,5]$. Industry 4.0 is also expected to bring environmental benefits, such as reduction in energy consumption and reduction in the amount of waste generated $[5,6]$.

Although the technologies related to Industry 4.0. are widely described in the literature, the organizational factors influencing the implementation of this concept in the enterprise have been studied to a much lesser extent [7]. Nevertheless, the main barriers to implementing Industry 4.0 include the following: lack of skilled workforce, lack of financial resources, concerns about cybersecurity, and organizational resistance (see [8]). On the other hand, researchers identified driving forces of Industry 4.0 as growing competition, striving to improve sustainability, innovation, productivity, 
and firm performance (see [8]). Nevertheless, human resources, their competences and skills, openness to change, and willingness to learn are crucial for adoption of Industry $4.0[7,8]$.

As Horváth and Szabó [8] noted, small- and medium-sized enterprises (SMEs) usually have higher barriers and lower driving forces of Industry 4.0 in comparison to multinational enterprises. Similarly, previous studies indicated that SMEs are less capable of coping with technological, financial, and human resources challenges regarded to Industry 4.0 than large enterprises [9]. Lack of knowledge, a short-term strategy mindset, a manager's attitude towards Industry 4.0, costs, and uncertain return on investment may be of key importance for the development of Industry 4.0 in SMEs $[9,10]$. Thus, the development of Industry 4.0 in SMEs may be different than in large enterprises [11,12], which results from the characteristics of SMEs. Compared to large enterprises, SMEs tend to have limited human, knowledge, and financial resources [13]. On the other hand, they are less formalized and more flexible, thanks to which they have the ability to adapt faster to changes in the environment [14-16].

Industry 4.0 is considered an innovation in the manufacturing sector [17]. Therefore, similar factors may have an impact on both an innovation implementation and an adoption of Industry 4.0 in a company. Previous studies indicated the significant relationships between introducing innovations and the presence of an appropriate culture in an organization [18-20] and knowledge-sharing [21]. Open-minded and flexible culture is expected to support Industry 4.0 implementation [7]. Results of research conducted in SMEs indicate that knowledge-sharing has a significant positive impact on technological innovation capability [22]. Moreover, it was found that there is a correlation between innovation and financial performance [23], although the direction of the causality effect between them is not obvious [24]. Introducing innovation may improve firm performance, but, on the other hand, only SMEs in a good financial condition may have adequate resources to introduce capital-intensive innovation [24]. However, there is a lack of empirical studies which explain the impact of organizational culture, knowledge-sharing, and firm performance on Industry 4.0 implementation in SMEs. To fill the research gap, the purpose of this study is to empirically examine the relationships between these constructs. This study is expected to answer the question of whether open-mindedness culture, knowledge-sharing, and firm performance have a positive impact on willingness to implement Industry 4.0 in SMEs.

The paper is organized as follows. Section 2 highlights the importance of the organizational culture, knowledge-sharing, and firm performance in facilitating the implementation of Industry 4.0 in SMEs. The five hypotheses are stated. Section 3 describes the methodology of the empirical research. Results are reported in Section 4. Theoretical and practical implications, limitations, and further studies are discussed in Section 5.

\section{Literature Review}

\subsection{Open-Mindedness Culture and Industry 4.0}

Organizational culture is a set of views, values, beliefs, and assumptions that are shared by members of the organization and thus determine their behaviors there [25]. Organizational culture performs integrating and coordinating functions [26]. It integrates members around organizations, gives them a sense of identity and stability of the social system. A shared system of values and meanings facilitates communication and mutual understanding [26]. Organizational culture provides organization members with guidelines for acceptable, valued, and undesirable behavior. The strength of organizational culture depends on the degree to which members of the organization are homogeneous in their perceptions of organizational values, norms, and practices [25]. Moreover, organizational culture cannot be easily copied, therefore it can be an element of building a competitive advantage of an enterprise [25].

Thus, organizational culture can affect employees' attitudes towards changes, implementation of innovative solutions, including the concept of Industry 4.0, if innovation is one of the main values of the adopted organizational culture [20]. The empirical research indicates a significant relationship 
between organizational culture and innovation $[19,27,28]$. However, it is crucial to indicate what type of culture fosters innovation.

Naranjo-Valencia et al. [20] analyzed the relationship between the innovation of Spanish organizations and four types of cultures, i.e., an adhocratic, clan, market, and hierarchy culture. It was found that the adhocratic culture is the best innovation predictor. In the adhocratic culture, flexibility, creativity, entrepreneurship, and risk-taking are appreciated. This type of culture is characteristic for companies oriented externally, operating in a dynamic environment and aspiring to be a market leader. Research conducted by Naranjo-Valencia et al. [20] also showed that the hierarchy culture in organizations has a negative effect on innovation. Control and internal orientation are characteristics of hierarchy culture companies. This type of culture emphasizes efficiency and strict compliance with standards, procedures, and regulations.

More recently, Wu et al. [28] investigated the impact of organizational culture on product and process innovations in manufacturing SMEs in Taiwan. Three types of organizational cultures were considered: trust and support, bureaucratic, and innovation culture. Results of that study showed that innovation culture, in conjunction with an appropriate operation strategy, has the strongest positive impact on innovation. Innovation culture, similar to the abovementioned adhocratic culture, focuses on openness, creativity, opportunity-seeking, and risk-taking [28]. In such a culture, employees are rewarded for courage and seeking new ways to perform their tasks.

Organizational culture in a specific organization is unique and features a combination of different values and practices. However, there is general consensus that such characteristics as creativity, freedom/autonomy, and a risk-taking attitude support innovation [20]. Thus, organizational culture which values those characteristics is expected to support innovative solutions, including Industry 4.0. Moreover, some scholars claim that open-mindedness plays a significant role in innovation [29], which includes the ability to question long-term practices and views. In open-mindedness culture, managers encourage employees to question existing beliefs, procedures, and assumptions; besides, original ideas are highly valued [30-32]. Open-minded individuals are likely to be more creative [33] and perceive changes in a company as a chance to improve [34]. Thus, open-minded culture links creativity, freedom, and reflection on current knowledge. Therefore, the following hypothesis is proposed:

Hypothesis 1. A relationship exists between the open-mindedness culture and willingness to implement Industry 4.0 in SMEs.

\subsection{The Open-Mindedness Culture, Knowledge-Sharing, and Industry 4.0}

Knowledge-sharing (KS) in an organization is a process of exchanging knowledge and experience between employees and teams in an organization in order to supplement employees' knowledge with new, valuable, and useful knowledge in order to achieve personal and organizational goals [21,22,35]. Knowledge is shared using various channels, including: discussions, conference networks, mentoring and training sessions, and databases [15,32,36]. The type of channel used depends on the type of knowledge being shared. From the epistemological point of view, knowledge sharing includes explicit and tacit knowledge; while from the ontological dimension, knowledge is individual, group, organizational, or inter-organizational [22]. Taking into account the source of knowledge, external and internal knowledge sharing is distinguished [37]. Moreover, knowledge-sharing behaviors are divided into knowledge donating and knowledge collecting [38].

Previous studies indicate that KS plays an important role in supporting various types of innovation-related activities and processes in an organization or even firm performance [15,39]. It was found that knowledge-sharing stimulates organizational learning [40], intellectual capital [39], employee's creativity [41,42], and innovative work behavior [43]. Based on a meta-analysis of antecedents of innovation, Hülsheger et al. [44] concluded that communication is fundamental in the development of innovation in the workplace. Collecting knowledge from different sources, recognizing various viewpoints and perspectives should lead to generating, testing, and implementing 
new solutions [44]. Maintaining contact with people outside one's own team may be of particular importance, as these contacts allow the acquisition of more diverse knowledge and, as a consequence, create fresh ideas. In particular, researchers emphasize that knowledge-sharing enables obtaining an effect of knowledge synergy [45], faster problem-solving, and quick response to changes in the organization's environment [21], reduces unnecessary learning efforts [46], evokes reflection on current knowledge, its reinterpretation and recombination [47,48], and helps keep employees aware of current problems and future challenges [49]. Knowledge-sharing is particularly important in the implementation of complex projects in enterprises operating in highly innovative, technology-intensive and knowledge-based sectors [22,50].

Although many studies confirm positive correlation between KS and process or technological innovations [21,22,51], there is no research on the relationship between KS and the implementation of Industry 4.0 in SMEs. However, KS can play an equally important role in implementing Industry 4.0 as it does in the case of innovation. Therefore, the following hypothesis is proposed:

Hypothesis 2. A relationship exists between knowledge-sharing and willingness to implement Industry 4.0 in SMEs.

Appropriate organizational culture is seen to have crucial impact on knowledge-sharing behaviors in an organization [51,52]. Such organizational values as openness, support, collaboration, and trust increase employees' propensity to share knowledge [52]. On the other hand, competition among employees, lack of recognition, and lack of job security lead to knowledge withholding [53]. Yang et al. [51] found that collaborative culture, which emphasizes such values as openness, teamwork, communication, change, and risk, positively affects employees' knowledge-sharing behavior. Mueller [54] confirmed empirically that open-mindedness (in the paper called openness) stimulates KS between project teams. Similar results were obtained by Liao [55] and Wah et al. [56]. In an open-minded environment employees are not afraid of sharing knowledge and ideas, because they trust that their original ideas will not be disregarded but appreciated [56].

Literature suggests correlation between open-mindedness and KS; however, the direct relationship between the open-mindedness culture and KS in SMEs is not examined sufficiently. To address this gap, the following hypothesis is stated:

Hypothesis 3. A relationship exists between the open-mindedness culture and knowledge-sharing in SMEs.

The above considerations indicate that open-mindedness culture has a positive impact on knowledge-sharing, which in turn increases willingness to implement Industry 4.0. KS can therefore act as a bridge combining open-mindedness with the implementation of innovative solutions. Developing open-mindedness culture in the organization creates conditions conducive to KS behaviors and using knowledge to introduce changes and experimentation. As Lin et al. [57] noted, "An open-minded organization, including SMEs, is more likely to devote resources and support systems to facilitate knowledge acquisition and sharing ( ... ) and further enhance their employees to utilize new knowledge for new product development" (p. 5). An analogous mediating effect of KS has been observed in the relationships between collaborative culture and innovation $[51,58]$, and between transformational leadership and innovation [21,49]. Thus, the following hypothesis is stated:

Hypothesis 4. Knowledge-sharing mediates the positive effect of open-mindedness culture on willingness to implement Industry 4.0 in SMEs.

\subsection{Firm Performance and Industry 4.0}

The aims of implementing Industry 4.0 solutions are not only a higher level of automatization and increase flexibility in production, but also improving operational efficiencies and growth in productivity [59-61]. However, the literature suggests a two-way relationship between the 
implementation of innovative solutions and firm performance. There is general consensus that the implementation of innovation improves the firm's results [23,62,63]. Moreover, empirical studies have confirmed that the adoption of Industry 4.0 technologies has a positive impact on firms' financial performance [64]. Research conducted in SMEs revealed that elements of Industry 4.0, such as big data, Internet of Things, and smart factory, have a positive effect on sustainable business performance, via the mediating role of information technology implementation [65].

On the other hand, past healthy firm performance paves the way for innovation $[24,66]$. The implementation of the Industry 4.0 concept in a firm is a complex activity that requires the involvement of various resources, including significant financial ones. Because of limited resources, Industry 4.0 adoption is a particularly difficult challenge for SMEs [65]. As suggested by Nguyen et al. [24], a firm in good financial standing is able to accumulate sufficient resources to conduct innovative, risky, and capital-intensive activity. In contrast, firms with poor performance and without access to external funding sources may not be able to implement radical Industry 4.0 solutions. This can lead to a vicious circle: firms with weak performance do not have sufficient resources to conduct innovation activities, which in turn leads to weak firm performance and consequently to poor innovation in the future and poor competition in the market [24]. The impact of firm performance on innovation has been confirmed in research by Rukundo [66]. The author concluded that "firms that increase their sales are more able to introduce new or substantially improved products or services or processes" (p. 242). This relationship can be explained by the fact that the good financial standing of the firm allows the expansion of research and development activities and the development of human resources (e.g., employee training, employing specialists), which are the basis for implementing innovative solutions.

Taking into account the above considerations, it can be assumed that the better the financial situation of an enterprise, the greater its ability and readiness to implement solutions innovations. Therefore:

Hypothesis 5. A relationship exists between financial performance and willingness to implement Industry 4.0 in SMEs.

\subsection{The Hypothesized Model}

The literature review and hypotheses stated in previous subsections are the source of the research model which is presented in Figure 1. The research model assumes that open-mindedness culture, knowledge-sharing, and financial performance have a significant and positive impact on willingness to implement Industry 4.0 in SMEs. Moreover, the model takes into account the mediating role of knowledge-sharing in the relationship between open-mindedness culture and Industry 4.0.

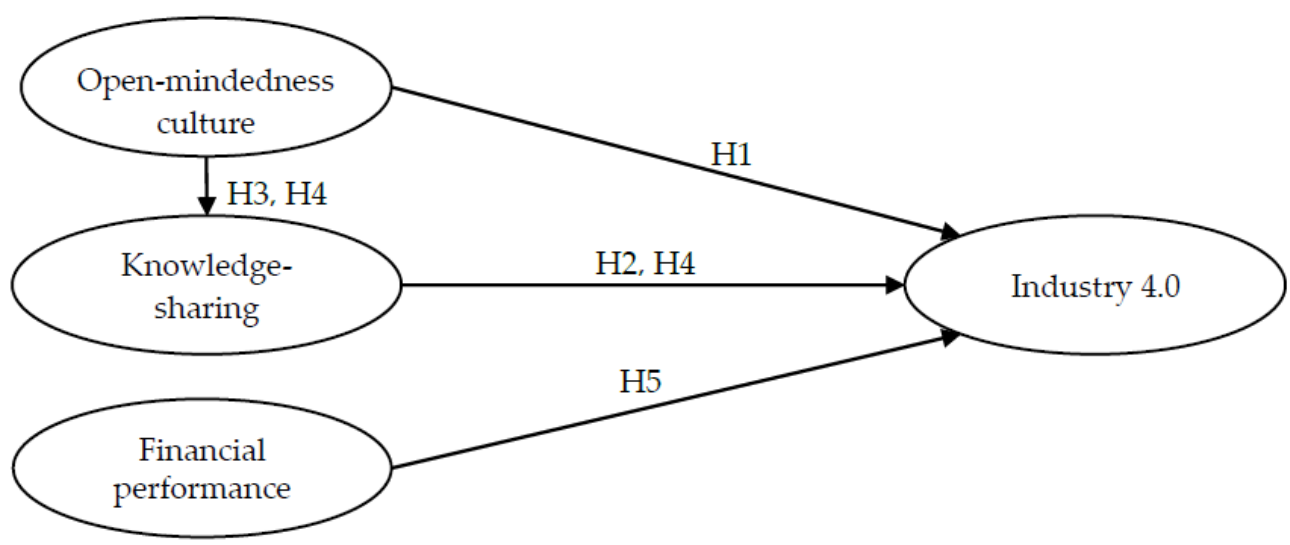

Figure 1. The hypothesized model. 


\section{Materials and Methods}

In order to examine the relationships between open-mindedness culture, knowledge-sharing, firm performance, and Industry 4.0, a quantitative study among SMEs was conducted. Positivist and explanatory approaches (see [67]), as well as a cross-sectional design were used in this study.

\subsection{Sample and Data Collection}

The research was conducted among Polish manufacturing small- and medium-sized enterprises. Manufacturing companies were selected due to the fact that Industry 4.0 solutions are primarily intended for production processes [68]. Data collection was commissioned by a professional research company. The ordering party was the Faculty of Organization and Management, Silesian University of Technology (Poland). Data collection using an anonymous questionnaire lasted from December 2019 to March 2020. A link to the questionnaire was sent to SMEs by e-mail. Respondents constituted top managers in SMEs. Top managers have the broadest view of the enterprise and have access to financial data [69], and thus were suitable respondents for this study. Data were collected from 562 SMEs, 265 of which were microenterprises (employing up to 10 employees), 221 were small enterprises (10-49 employees), and 76 were medium enterprises (50-249 employees). Due to the age of the company, the sample consisted of the following companies: aged up to 5 years-167; between 6 and 10 years-79; between 11 and 15 years - 75; between 16 and 20 years - 61; more than 20 years-180.

The items used in this study were part of a large and multi-scale questionnaire, therefore respondents were unlikely to guess the aim of it. Thus, the impact of the method biases on results was reduced [70]. To estimate the common method bias (CMB), a Harman single factor test [71] was conducted. The results revealed that the single factor accounted for $29.1 \%$ of the total variance, thus below the threshold of 50 per cent. Hence, $\mathrm{CMB}$ was not likely to be a serious issue in this study.

\subsection{Measures}

Items of the questionnaire were measured using a five-point Likert scale, where 1 -disagree, 2-rather disagree, 3-difficult to say, 4-rather agree, and 5-agree. Open-mindedness culture was measured using four items taken from Baker and Sinkula [30] completed with one item, "Problems, failures and experiences are discussed openly to avoid making similar mistakes in the future", adapted from Saini [72] and Wah et al. [56]. In the case of other scales, items were generated on the basis of literature analysis and previously used measures in empirical research. In the case of knowledge-sharing in an organization, three items were generated by analyzing the work of researchers such as Darroch [73] and Wang et al. [74]. Financial performance (FP) can be measured using a variety of measures (see $[75,76]$ ); however, this study was limited to three commonly used measures of financial performance, including return on investment, profitability, and revenue growth. As accurate financial data are not readily disclosed by companies, respondents were asked to compare profitability and revenue growth with that of competitors. In the case of the willingness to implement Industry 4.0 (I) in SMEs construct, a ready-made scale was not used due to the lack of such a scale in the literature. To measure willingness to implement Industry 4.0 in SMEs, four items were generated, bearing in mind the research objective. The purpose of these items was to reflect the overall plans of companies to implement Industry 4.0 solutions. Therefore, two items concerned plans to increase the degree of digitization, computerization, and automation in the next 3-5 years. The next item covered financial perspective and concerned plans to increase investment expenditure related to Industry 4.0. In the last, fourth, item the company was compared to the competitors in terms of development and implementation of Industry 4.0 solutions. Such a set of items made it possible to assess the willingness to implement Industry 4.0 from different perspectives and to give a more complete picture of the studied phenomenon in the company. Items used in this study are presented in Table 1. Additionally, company size and age were taken as control variables in this study. 
Table 1. Constructs and items

Question
Item
OMC1
OMC2
OMC3
In our company, managers encourage employees to "think outside of the box".
Original ideas are highly valued in this organization.
WhC are not afraid to reflect critically on the shared assumptions
we have about the way we do business. *

Note: (R)—reverse scored; * items deleted after confirmatory factor analysis.

\subsection{Data Analysis}

Partial least squares path modeling (PLS-PM) with SmartPLS 3.3.2 (SmartPLS GmbH: Boenningstedt, Germany) [77] was used to analyze the hypotheses of this study. PLS-PM is a variance-based estimator for structural equation modeling (SEM) and, compared to covariance-based SEM, it requires no distributional assumptions on observed variables and works well both with small and large sample sizes [78]. Moreover, PLS can be applied in various types of research, including exploratory, confirmatory, and explanatory [79], but it is particularly useful in predictive studies [80]. In this study the kurtosis and skewness values for the six variables were less than -1 or greater than 1 , indicating that the data were non-normally distributed. Moreover, this study was explorative and focused on the prediction of the dependent variable rather than confirming theory. Therefore, in spite of the controversy regarding PLS-PM advantages and limitations [78,81], PLS-PM was selected as an appropriate method for this study. Analysis with PLS consists of two main steps: (1) testing the measurement model and (2) assessment of the structural model.

\section{Results}

\subsection{Measurement Model}

In this study, all constructs were reflective. Assessing reflective measurement models includes reliability and validity of the constructs [78]. Examining the indicator loadings revealed that two items, OMC3 and OMC4, had factor loading values of 0.572 and 0.232 , respectively, which is far lower than the minimum recommended value of 0.7. Therefore, OMC3 and OMC4 were deleted from the model, which was then retested. As part of the reliability test of the measurement model, Cronbach's Alpha, rho_A, and composite reliability (CR) were used to check internal consistency 
reliability. The Cronbach's Alpha values of the constructs ranged from 0.72 to 0.79 , rho_A ranged from 0.73 to 0.80 , while $C R$ measures ranged from 0.84 to 0.86 (Table 2). These values are higher than the minimum recommended value of 0.7 [78].

Table 2. Reliability and validity.

\begin{tabular}{|c|c|c|c|c|c|c|c|c|c|c|}
\hline Construct & Mean & SD & $\mathrm{C} \alpha$ & rho_A & CR & AVE & Item & Loading & Kurtosis & Skewness \\
\hline \multirow[t]{3}{*}{ OMC } & 3.98 & 0.85 & 0.73 & 0.73 & 0.85 & 0.65 & OMC1 & 0.748 & -0.716 & -0.654 \\
\hline & & & & & & & OMC2 & 0.836 & 1.470 & -1.167 \\
\hline & & & & & & & OMC5 & 0.834 & 1.482 & -1.266 \\
\hline \multirow[t]{3}{*}{ KS } & 3.41 & 0.99 & 0.75 & 0.78 & 0.85 & 0.66 & KS1 & 0.718 & -1.253 & -0.138 \\
\hline & & & & & & & KS2 & 0.869 & -0.043 & -0.828 \\
\hline & & & & & & & KS3 & 0.844 & -0.385 & -0.452 \\
\hline \multirow[t]{3}{*}{$\mathrm{FP}$} & 3.26 & 0.71 & 0.72 & 0.73 & 0.84 & 0.65 & FP1 & 0.709 & 0.515 & -0.961 \\
\hline & & & & & & & FP2 & 0.833 & 1.405 & 0.078 \\
\hline & & & & & & & FP3 & 0.860 & 1.386 & -0.027 \\
\hline \multirow[t]{4}{*}{ I } & 2.96 & 0.99 & 0.79 & 0.80 & 0.86 & 0.61 & I1 & 0.801 & -0.893 & -0.398 \\
\hline & & & & & & & I2 & 0.753 & -1.242 & -0.070 \\
\hline & & & & & & & I3 & 0.823 & -0.859 & -0.280 \\
\hline & & & & & & & $\mathrm{I} 4$ & 0.742 & -0.789 & 0.213 \\
\hline
\end{tabular}

\footnotetext{
Note: OMC 3 and OMC4 items were removed from the instrument because their factor loadings are below a minimum criterion. OMC-Open-mindedness culture, KS-Knowledge-sharing, FP-Financial performance, I-Industry 4.0, SD—Standard Deviation, C $\alpha$-Cronbach's Alpha, CR-Composite Reliability, AVE-Average Variance Extracted.
}

Assessing validity of the measurement model included the convergent and discriminant validity. The convergent validity was assessed by checking average variance extracted (AVE). AVE for all constructs was higher than the minimum recommended value of 0.5 [78]. Discriminant validity was estimated using cross-loading, the square root of the AVE (Fornell-Larcker criterion), and the heterotrait-monotrait ratio of correlations (HTMT). The results of cross-loading show that all items were loaded higher on their assigned constructs than on other ones. The square root of the AVE of each construct was greater than the correlations (Table 3). Finally, the HTMT values were lower than a threshold of 0.85 [78], which confirms the discriminant validity. In summary, the results indicate that the measurement model has good reliability and validity.

Table 3. Construct correlations and square root of average variance extracted and heterotrait-monotrait ratio of correlations (HTMT) values.

\begin{tabular}{cccccc}
\hline & Construct & $\mathbf{1 .}$ & $\mathbf{2 .}$ & $\mathbf{3 .}$ & $\mathbf{4 .}$ \\
\hline 1. & Open-mindedness culture & $\mathbf{0 . 8 0 7}$ & 0.767 & 0.356 & 0.401 \\
2. & Knowledge sharing & $0.587^{*}$ & $\mathbf{0 . 8 1 3}$ & 0.384 & 0.380 \\
3. & Financial performance & $0.255^{*}$ & $0.288^{*}$ & $\mathbf{0 . 8 0 3}$ & 0.439 \\
4. & Industry 4.0 & $0.310^{*}$ & $0.307^{*}$ & $0.347^{*}$ & $\mathbf{0 . 7 8 1}$ \\
\hline
\end{tabular}

Note: ${ }^{*} p<0.001$. The bold diagonal elements represent the square root of AVE. Values below the diagonal are the construct correlations. Values above the diagonal are the HTMT values.

\subsection{Structural Model}

Assessment of the structural model included such criteria as the coefficient of determination $\left(R^{2}\right)$, Stone-Geisser's $Q^{2}$ value, fit indices, and the statistical significance of the path coefficients. The adjusted $\mathrm{R}^{2}$ values were 0.180 for I and 0.344 for KS (Figure 2). This means that the $\mathrm{R}^{2}$ values in this model were low $\left(R^{2}<0.3\right)$ and moderate $\left(0.3<R^{2}<0.6\right)$ [82]. The predictive relevance was assessed with $Q^{2}$ values by using blindfolding procedure. The $\mathrm{Q}^{2}$ value for I was 0.102 and for KS -0.217 . These values exceed zero, which confirms predictive accuracy of the structural model (Hair et al., 2019). The general model fit indices were as follows: SRMR $=0.088$ (acceptable if $<0.1$ ) [83], d_ULS $=0.697, d \_G=0.219$, chi-square $=736.579, \mathrm{NFI}=0.707$ and RMS theta $=0.217$. 


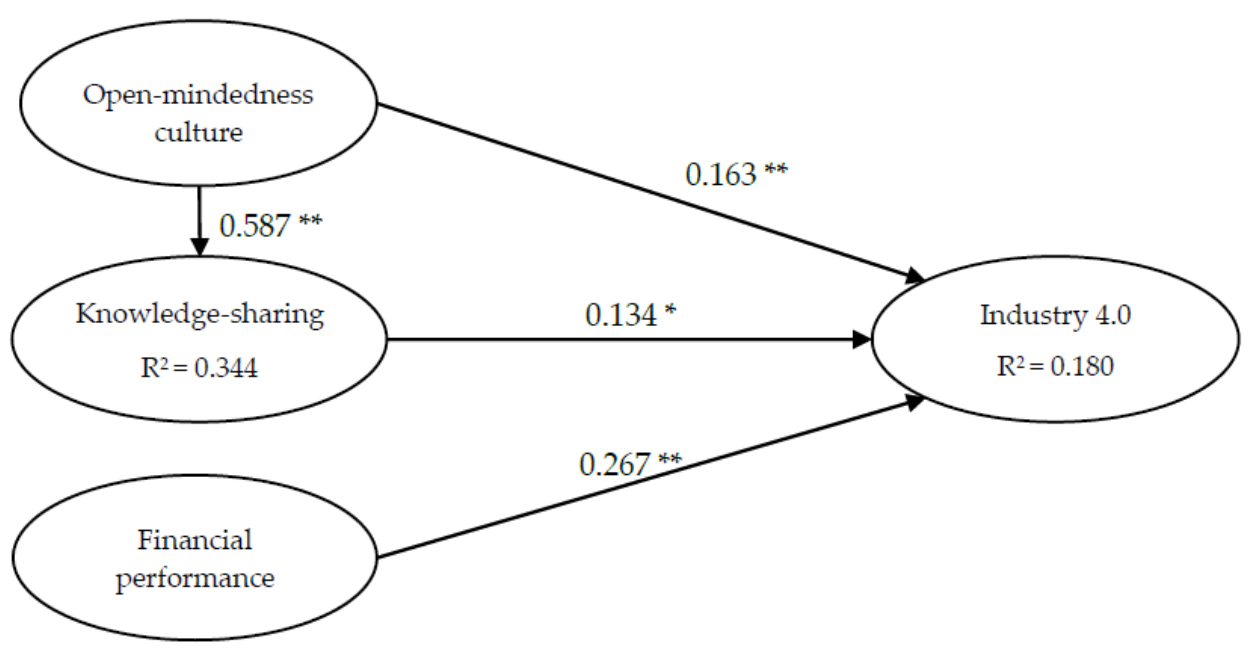

Figure 2. Structural model path coefficients. Note: ${ }^{*} p<0.01 ;{ }^{* *} p<0.001$. R square adjusted.

The bootstrapping technique with 5000 resamples was used to evaluate the path coefficients and their significance levels. The results presented in Table 4 show that all three constructs, i.e., open-mindedness culture, knowledge-sharing, and financial performance, have a positive impact on willingness to implement Industry 4.0 in SMEs. These results support hypotheses H1, H2, and H5. Moreover, consistent with the expectation, open-mindedness culture is strongly positively associated with knowledge-sharing. Therefore, $\mathrm{H} 3$ is supported.

Table 4. Structural model results.

\begin{tabular}{|c|c|c|c|c|c|c|}
\hline Hypothesis & $\begin{array}{l}\text { Suggested } \\
\text { Effect }\end{array}$ & $\begin{array}{l}\text { Path } \\
\text { Coefficient }\end{array}$ & t-Value & $p$-Value & $95 \%$ BCa CI & Support \\
\hline $\begin{array}{l}\text { H1: Open-mindedness } \\
\text { culture } \rightarrow \text { Industry } 4.0\end{array}$ & + & 0.163 & 3.527 & 0.000 & (0.069; 0.251)Sig. & Yes \\
\hline $\begin{array}{l}\mathrm{H} 2: \text { Knowledge-sharing } \rightarrow \\
\text { Industry } 4.0\end{array}$ & + & 0.134 & 2.633 & 0.008 & (0.034; 0.236)Sig. & Yes \\
\hline $\begin{array}{l}\text { H3: Open-mindedness } \\
\text { culture } \rightarrow \\
\text { Knowledge-sharing }\end{array}$ & + & 0.587 & 17.550 & 0.000 & (0.513; 0.646)Sig. & Yes \\
\hline $\begin{array}{l}\text { H5: Financial performance } \\
\quad \rightarrow \text { Industry } 4.0\end{array}$ & + & 0.267 & 6.293 & 0.000 & (0.175; 0.342)Sig. & Yes \\
\hline
\end{tabular}

Note: $\mathrm{BCa} C \mathrm{I}=$ bias corrected confidence interval. Sig. $=$ a significant direct effect at 0.05 .

To test if knowledge-sharing mediates the positive effect of open-mindedness culture on willingness to implement Industry 4.0 in SMEs, a method proposed by Baron and Kenny [84] was adopted. First, a model without knowledge-sharing as a mediator was examined. In this model, there were significant path coefficients between open-mindedness culture and knowledge-sharing $(0.588)$ as well as between open-mindedness culture and Industry 4.0 (0.237). After introducing knowledge sharing as a mediator, it turned out that knowledge sharing was significantly related to Industry $4.0(0.134)$ and the direct path coefficients between open-mindedness culture and Industry 4.0 declined from 0.237 to 0.163 . However, despite the decrease, this direct path coefficient was still significant. As the results of bootstrapping indicate (Table 5), the indirect, direct, and total effects of open-mindedness culture on Industry 4.0 are statistically significant. To determine the extent to which the mediation process explains the variance of Industry 4.0, the variance accounted for (VAF) value was calculated [85]. The VAF value was 32\%, which suggests a partial mediation [86]. Hence, the hypothesis suggesting that knowledge-sharing mediates the positive effect of open-mindedness culture on willingness to implement Industry 4.0 in SMEs (H4) is supported. 
Table 5. Bootstrap test of direct, indirect, and total effects.

\begin{tabular}{ccccccc}
\hline Hypothesis & $\begin{array}{c}\text { Direct } \\
\text { Effect }\end{array}$ & $\mathbf{9 5 \% ~ B C a ~ C I ~}$ & $\begin{array}{c}\text { Indirect } \\
\text { Effect }\end{array}$ & 95\% BCa CI & $\begin{array}{c}\text { Total } \\
\text { Effect }\end{array}$ & 95\% BCa CI \\
\hline $\begin{array}{c}\text { H4: Open-mindedness culture } \\
\rightarrow \text { Knowledge-sharing } \rightarrow \\
\text { Industry 4.0 }\end{array}$ & 0.163 & $\begin{array}{c}(0.069 ; 0.253) \\
\text { Sig. }\end{array}$ & 0.079 & $\begin{array}{c}(0.020 ; 0.142) \\
\text { Sig. }\end{array}$ & 0.242 & $\begin{array}{c}(0.165 ; 0.315) \\
\text { Sig. }\end{array}$ \\
\hline
\end{tabular}

Note: $\mathrm{BCa} C \mathrm{C}=$ bias corrected confidence interval; Sig. $=$ a significant direct effect at 0.05 .

It was examined whether the size and age of the enterprise have an impact on the studied relationships between variables. For this purpose, multi-group analysis (MGA) was used. Taking into account company size, the path coefficients difference was statistically significant at the 5 per cent level for relationships between OMC and Industry 4.0 (Table 6). The path coefficient between OMC and Industry 4.0 was significant in microenterprises $(\beta=0.288 ; p<0.001)$, whereas among small enterprises the path coefficient was lower and insignificant $(\beta=0.080 ; p=0.287)$. At the 10 per cent level, there was significant difference in the path coefficients between KS and Industry 4.0. This path coefficient was insignificant in microenterprises $(\beta=0.028 ; p=0.707)$, but significant in small enterprises $(\beta=0.209$; $p<0.01$ ). In the case of company age, the youngest companies (aged up to five years, $n=167$ ) were compared with the oldest ones (aged above 20 years, $n=180$ ). Path coefficients differences were not statistically significant in these two groups.

Table 6. Multi-group analysis by company size.

\begin{tabular}{cccccccccc}
\hline \multirow{2}{*}{ Relationship } & \multicolumn{3}{c}{ Path Coefficient } & \multicolumn{3}{c}{ Micro vs. Small } & Micro vs. Medium & \multicolumn{2}{c}{ Small vs. Medium } \\
\cline { 2 - 9 } & Micro & Small & Medium & P.c.diff. & $\boldsymbol{p}$-value & P.c.diff. & $\boldsymbol{p}$-value & P.c.diff. & $p$-Value \\
\hline $\mathrm{FP} \rightarrow \mathrm{I}$ & $0.256^{*}$ & $0.233^{*}$ & $0.238^{*}$ & 0.023 & 0.833 & 0.018 & 0.892 & -0.004 & 0.976 \\
$\mathrm{KS} \rightarrow \mathrm{I}$ & 0.028 & $0.209^{*}$ & 0.247 & -0.181 & 0.091 & -0.218 & 0.207 & -0.037 & 0.828 \\
$\mathrm{OMC} \rightarrow \mathrm{I}$ & $0.288^{*}$ & 0.080 & 0.159 & 0.208 & 0.032 & 0.129 & 0.435 & -0.079 & 0.656 \\
$\mathrm{OMC} \rightarrow \mathrm{KS}$ & $0.562 *$ & $0.609^{*}$ & $0.660^{*}$ & -0.047 & 0.498 & -0.097 & 0.325 & -0.051 & 0.628 \\
\hline
\end{tabular}

Note: Acronyms used in this table are listed in Table 1. P.c.diff.-Path coefficients difference. ${ }^{*}$ a significant direct effect at 0.05 .

\section{Discussion and Conclusions}

\subsection{Summary of the Main Research Results}

This research proposed a model of interrelationships between open-mindedness culture, knowledge-sharing, financial performance, and willingness to implement Industry 4.0 in manufacturing SMEs. The results of this research support all five hypothesis. The main results reported in the current study are as follow:

- There is a positive relationship between the open-mindedness culture and willingness to implement Industry 4.0 in SMEs;

- A positive relationship exists between knowledge-sharing and willingness to implement Industry 4.0 in SMEs;

- The antecedent of knowledge-sharing is open-mindedness culture;

- Knowledge-sharing mediates the positive effect of open-mindedness culture on willingness to implement Industry 4.0 in SMEs;

- Financial performance has a positive impact on willingness to implement Industry 4.0 in SMEs.

Results of this research make it possible to draw theoretical and practical implications.

\subsection{Theoretical Contributions}

This study contributes to the theories of Industry 4.0 and innovation in the following ways.

Firstly, the study aimed at explaining the relationship between firm performance and Industry 4.0. A number of researchers indicated that it is the implementation of innovation that is to both improve 
operational performance and bring financial benefits to the company $[23,62,63]$. However, this study considered another direction of such a relationship. Results of this study show that both in general SMEs surveyed, and in groups differing in size (micro-, small-, and medium-sized enterprises) financial performance was significantly and positively related to willingness to implement Industry 4.0 in an organization, supporting Hypothesis 5. This result is consistent with previous research suggesting that good financial standing of the company is a factor that allows a company to get involved in implementing innovative solutions [66]. As Müller et al. [87] noted, limited finances and human resources make it difficult for many SMEs to go beyond current technical capabilities and identify new technologies. Moreover, SMEs are concerned about taking risks and investing limited financial resources in technologies with uncertain results. Thus, the relationship between financial performance and an adoption of Industry 4.0 in SMEs may be bidirectional—good financial standing facilitates an implementation of Industry 4.0 in SMEs, which in turn improves firm performance. This finding is particularly important for SMEs, which usually have limited opportunities to obtain external sources for financing investments and must rely on their own funds.

Secondly, although organizational culture and KS are regarded as the main determinants of organization innovation, previous studies have not investigated open-mindedness culture and KS in the context of Industry 4.0 implementation. To fill the research gaps, this study proposes a mediation research model covering these constructs. The results of this study confirm the significant role of organizational culture and knowledge-sharing for the implementation of Industry 4.0 solutions. More specifically, open-mindedness culture has both a direct and indirect, through knowledge-sharing, impact on willingness to implement Industry 4.0 in SMEs (supporting Hypotheses 1 and 4). This finding is consistent with previous studies, which indicated the relationship of both the appropriate organizational culture $[19,27,28]$ and the sharing of knowledge $[21,22,51]$ with innovation. This study highlights the role of open-mindedness culture, which values creativity and reflection on current knowledge. Similarly, Veile et al. [7], based on interviews with managers from Industry 4.0-experienced German manufacturing companies, concluded that in order to support Industry 4.0, "corporate culture should be characterized by flexibility, openness, willingness to learn and an entrepreneurial mindset" (p. 17). Moeuf et al. [10] concluded that Industry 4.0 is a space for creativity and new opportunities and requires engineers with multidisciplinary visions and open-mindedness.

Moreover, in this study the relationship between open-mindedness culture and willingness to implement Industry 4.0 was the strongest among microenterprises. This may be due to the specifics of microenterprises that employ a small number of people. In such conditions, the direction of the company's development, including the implementation of innovative solutions, depends primarily on the manager/owner-their personality, openness, creativity, and a tendency to make bold and risky decisions. Sharing knowledge in the smallest enterprises is less important for the implementation of Industry 4.0, which was confirmed by this study. In general, the surveyed enterprises showed a significant relationship between KS and Industry 4.0, while in the group of microenterprises no statistical significance was found. It can be concluded that due to the small number of employees, organizational solutions in the field of knowledge sharing are not as crucial in microenterprises as in the larger ones. Nevertheless, this study confirmed that KS is an important antecedent of willingness to implement Industry 4.0 in SMEs, thus supporting Hypothesis 2. This is in line with previous findings that communicating with employees about the objectives of the Industry 4.0 project is one of the critical success factors in the adoption of Industry 4.0 in SMEs [10].

Finally, previous empirical studies of the relationship between open-mindedness and knowledge-sharing in the workplace are still scarce and researchers called for exploring this relationship in different national settings [56] and using larger sample sizes [54]. To respond to these calls, this paper has examined these relationships among 562 Polish SMEs and confirmed their significance, and thus Hypothesis 3. Moreover, this relationship is strong and significant regardless of the size of SMEs. This result is in line with earlier studies, according to which an appropriate organizational culture that values openness and creativity facilitates and supports knowledge-sharing 
within the organization [51,52]. Moreover, this study indicates that KS also acts as a mediator between open-mindedness culture and willingness to implement Industry 4.0. This is in line with the suggestion proposed by Lin et al. [57] that an open-minded organization is willing to sacrifice its resources and support systems to support knowledge-sharing within the organization and thus help employees generate and implement innovative solutions.

\subsection{Practical Contributions}

This study provides a better understanding of the relationship between OMC, KS, FP, and Industry 4.0. Therefore, the results of this study may be useful for managers/owners interested in implementing Industry 4.0 in SMEs. Managerial implications are as follows.

Firstly, SME managers can strengthen willingness to implement Industry 4.0 by building open-mindedness culture. Managers should support such behaviors as openness to fresh ideas, creativity, critical reflection, reviewing and questioning old knowledge and procedures. However, as Hernández-Mogollon et al. [29] noticed, the creation of open-mindedness might be a substantial challenge for managers in SMEs because of cultural barriers. In SMEs, the development of a company depends on the founder or owner, who is also often a manager. Therefore, they are responsible for shaping an open organizational context. However, as Cegarra and Wensley [88] note, it is often only in times of crisis that founders or owners are inclined to question the deeply rooted routines in the organization. Hence, the managers in SMEs should be aware of the role of open-mindedness and its barriers. On the one hand, managers have to overcome such barriers as being resistant to change, no tolerance of failure, and blame culture [29]. On the other hand, they should engage in cultivating flexible culture and open new ways of thinking and performing things. The great importance of open-mindedness for the implementation of the Industry 4.0 is particularly observed in microenterprises.

Secondly, willingness to implement Industry 4.0 is also supported by knowledge-sharing. This relationship is pronounced in enterprises larger than microenterprises. This result should encourage managers to develop solutions that support knowledge-sharing in an organization. Regular meetings with employees during which information about competition and trends in the industry is provided, a remuneration system promoting knowledge-sharing, and IT infrastructure facilitating access to the necessary knowledge are examples of solutions that can be used. The larger the SME is, the more formalized and complicated its organizational structure, and thus the more difficult internal communication is. Thus, the larger the enterprise, the more demanding it becomes to build an effective knowledge-sharing system.

Finally, the results of this research make managers realize that one of the important factors influencing the willingness to implement Industry 4.0 is the company's financial condition. Implementing Industry 4.0 needs high investments in technology, data security, and workers' skills, but return on investments remains uncertain [4]. Nevertheless, Industry 4.0 seems to be an inevitable direction of transformation of manufacturing SMEs that want to compete successfully in global markets. A good financial situation of SME will facilitate this transformation.

\subsection{Limitation and Further Studies}

This study has some limitations which can be overcome in further studies. Firstly, in this study subjective measures of financial performance were used. While this is a common approach in this type of research, additional objective financial indicators would improve the credibility of the study. In addition, longitudinal research could reveal whether the willingness to implement Industry 4.0 translates into the actual implementation of Industry 4.0. In future research, it is also worth checking whether there is an inverse relationship, i.e., whether the implementation of Industry 4.0 improves financial performance in SMEs.

Secondly, the research model does not take into account environmental conditions and their impact on willingness to implement Industry 4.0. Previous research showed that such variables as 
environmental dynamism and competitiveness can moderate the relationship between innovation and financial performance [89]. Therefore, the existence of environmental variables in the research model will enrich findings.

Thirdly, the reliability and validity of scales should be confirmed. After confirmatory factor analysis, the scale for open-mindedness culture has changed compared to the original one. New scales for knowledge-sharing and willingness to implement Industry 4.0 were developed. Although a decent sample size was used and assessment of the measurement model confirmed good reliability and validity of the scales, confirmation of the suitability of these scales is recommended in future research.

Finally, data collection in this study was based on a self-reported questionnaire and as a consequence common method bias might affect the research results. To minimize this, some remedies were applied, including ensuring the anonymity of the respondents and using a large and multi-scale questionnaire, thus the aim of the research was difficult to guess. A Harman single factor test indicated that common method bias was not likely to be a serious issue in this study. However, using archival data and multiple respondents from one company are recommended to prevent potential common method bias in future research.

Author Contributions: Conceptualization, A.M. and R.K.; methodology, A.M. and R.K.; validation, R.K.; formal analysis, R.K.; investigation, A.M.; writing-original draft preparation, R.K.; writing-review and editing, A.M.; visualization, R.K.; supervision, A.M.; project administration, A.M.; funding acquisition, A.M. All authors have read and agreed to the published version of the manuscript.

Funding: This paper was published as part of statutory research No. BK-239/ROZ-0/2020 at the Silesian University of Technology, Faculty of Organization and Management.

Conflicts of Interest: The authors declare no conflict of interest. The funders had no role in the design of the study; in the collection, analyses, or interpretation of data; in the writing of the manuscript, or in the decision to publish the results.

\section{References}

1. Li, D.; Fast-Berglund, Å.; Paulin, D. Current and future Industry 4.0 capabilities for information and knowledge sharing: Case of two Swedish SMEs. Int. J. Adv. Manuf. Technol. 2019, 105, 3951-3963. [CrossRef]

2. Kagermann, H. Recommendations for Implementing the Strategic Initiative INDUSTRIE 4.0: Securing the Future of German Manufacturing Industry; Final Report of the Industrie 4.0 Working Group; Forschungsunion: Berlin, Germany, 2013.

3. Khan, A.; Turowski, K. A Preliminary Study on Industry 4.0. J. Ind. Intell. Inf. 2016. [CrossRef]

4. Kiel, D.; Müller, J.M.; Arnold, C.; Voigt, K.-I. Sustainable industrial value creation: Benefits and challenges of industry 4.0. Int. J. Innov. Manag. 2017, 21, 1740015. [CrossRef]

5. Müller, J.M. Business model innovation in small- and medium-sized enterprises: Strategies for industry 4.0 providers and users. J. Manuf. Technol. Manag. 2019, 30, 1127-1142. [CrossRef]

6. Miśkiewicz, R.; Wolniak, R. Practical Application of the Industry 4.0 Concept in a Steel Company. Sustainability 2020, 12, 5776. [CrossRef]

7. Veile, J.W.; Kiel, D.; Müller, J.M.; Voigt, K.-I. Lessons learned from Industry 4.0 implementation in the German manufacturing industry. J. Manuf. Technol. Manag. 2019. Ahead of Print. [CrossRef]

8. Horváth, D.; Szabó, R.Z. Driving forces and barriers of Industry 4.0: Do multinational and small and medium-sized companies have equal opportunities? Technol. Forecast. Soc. Chang. 2019, 146, 119-132. [CrossRef]

9. Sommer, L. Industrial revolution-Industry 4.0: Are German manufacturing SMEs the first victims of this revolution? J. Ind. Eng. Manag. 2015, 8, 1512-1532. [CrossRef]

10. Moeuf, A.; Lamouri, S.; Pellerin, R.; Tamayo-Giraldo, S.; Tobon-Valencia, E.; Eburdy, R. Identification of critical success factors, risks and opportunities of Industry 4.0 in SMEs. Int. J. Prod. Res. 2020, 58, 1384-1400. [CrossRef]

11. Somohano-Rodríguez, F.M.; Madrid-Guijarro, A.; López-Fernández, J.M. Does Industry 4.0 really matter for SME innovation? J. Small Bus. Manag. 2020, 1-28. [CrossRef] 
12. Müller, J.M.; Buliga, O.; Voigt, K.-I. The role of absorptive capacity and innovation strategy in the design of industry 4.0 business Models-A comparison between SMEs and large enterprises. Eur. Manag. J. 2020. [CrossRef]

13. Ates, A.; Garengo, P.; Cocca, P.; Bititci, U. The development of SME managerial practice for effective performance management. J. Small Bus. Enterp. Dev. 2013, 20, 28-54. [CrossRef]

14. Krajňáková, E.; Navikaitè, A.; Navickas, V. Paradigm shift of small and medium-sized enterprises competitive advantage to management of customer satisfaction. Inž. Ekon. 2015, 327-332. [CrossRef]

15. Michna, A. The mediating role of firm innovativeness in the relationship between knowledge sharing and customer satisfaction in SMEs. Eng. Econ. 2018, 29, 93-103. [CrossRef]

16. Michna, A.; Kmieciak, R.; Czerwińska-Lubszczyk, A. Dimensions of Intercompany Cooperation in the Construction Industry and their Relations to Performance of SMEs. Eng. Econ. 2020, 31, 221-232. [CrossRef]

17. Osunsanmi, T.O.; Aigbavboa, C.; Oke, A. Construction 4.0: The Future of the Construction Industry in South Africa. Int. J. Civ. Environ. Eng. 2018, 12, 150-156.

18. Büschgens, T.; Bausch, A.; Balkin, D.B. Organizational Culture and Innovation: A Meta-Analytic Review: Organizational Culture and Innovation. J. Prod. Innov. Manag. 2013, 30, 763-781. [CrossRef]

19. Carmona, L.J.D.M.; Gomes, G.; Costa, D.d.L.C. Elements of organizational culture that encourage innovation development. Rev. Adm. FACES J. 2020, 19. [CrossRef]

20. Naranjo-Valencia, J.C.; Jiménez-Jiménez, D.; Sanz-Valle, R. Studying the links between organizational culture, innovation, and performance in Spanish companies. Rev. Latinoam. Psicol. 2016, 48, 30-41. [CrossRef]

21. Le, P.B.; Lei, H. Determinants of innovation capability: The roles of transformational leadership, knowledge sharing and perceived organizational support. J. Knowl. Manag. 2019, 23, 527-547. [CrossRef]

22. Yao, J.; Crupi, A.; Di Minin, A.; Zhang, X. Knowledge sharing and technological innovation capabilities of Chinese software SMEs. J. Knowl. Manag. 2020, 24, 607-634. [CrossRef]

23. Bigliardi, B. The effect of innovation on financial performance: A research study involving SMEs. Innovation 2013, 15, 245-255. [CrossRef]

24. Nguyen, D.; Nguyen, H.; Nguyen, K.S. Ownership feature and firm performance via corporate innovation performance: Does it really matter for Vietnamese SMEs? J. Asian Bus. Econ. Stud. 2018, 25, 239-250. [CrossRef]

25. Miron, E.; Erez, M.; Naveh, E. Do personal characteristics and cultural values that promote innovation, quality, and efficiency compete or complement each other? J. Organ. Behav. 2004, 25, 175-199. [CrossRef]

26. Martins, E.C.; Terblanche, F. Building organisational culture that stimulates creativity and innovation. Eur. J. Innov. Manag. 2003, 6, 64-74. [CrossRef]

27. Alofan, F.; Chen, S.; Tan, H. National cultural distance, organizational culture, and adaptation of management innovations in foreign subsidiaries: A fuzzy set analysis of TQM implementation in Saudi Arabia. J. Bus. Res. 2020, 109, 184-199. [CrossRef]

28. Wu, L.-F.; Huang, I.-C.; Huang, W.-C.; Du, P.-L. Aligning organizational culture and operations strategy to improve innovation outcomes: An integrated perspective in organizational management. J. Organ. Chang. Manag. 2019, 32, 224-250. [CrossRef]

29. Hernández-Mogollon, R.; Cepeda-Carrión, G.; Cegarra-Navarro, J.G.; Leal-Millán, A. The role of cultural barriers in the relationship between open-mindedness and organizational innovation. J. Organ. Chang. Manag. 2010, 23, 360-376. [CrossRef]

30. Baker, W.E.; Sinkula, J.M. The Synergistic Effect of Market Orientation and Learning Orientation on Organizational Performance. J. Acad. Mark. Sci. 1999, 27, 411-427. [CrossRef]

31. Cegarra-Navarro, J.-G.; Sánchez-Polo, M.T. Influence of the open-mindedness culture on organizational memory: An empirical investigation of Spanish SMEs. Int. J. Hum. Resour. Manag. 2011, 22, 1-18. [CrossRef]

32. Kmieciak, R. Improving SME performance through organizational memory: The role of open-mindedness culture. J. Organ. Chang. Manag. 2019, 32, 473-491. [CrossRef]

33. Reijseger, G.; Peeters, M.C.W.; Taris, T.W.; Schaufeli, W.B. From Motivation to Activation: Why Engaged Workers are Better Performers. J. Bus. Psychol. 2017, 32, 117-130. [CrossRef]

34. Samaranayake, S.U.; Takemura, T. Employee Readiness for Organizational Change: A Case Study in an Export Oriented Manufacturing Firm in Sri Lanka. Eurasian J. Bus. Econ. 2017, 10, 1-16. [CrossRef]

35. Mirzaee, S.; Ghaffari, A. Investigating the impact of information systems on knowledge sharing. J. Knowl. Manag. 2018, 22, 501-520. [CrossRef] 
36. Yang, J.-T. Individual attitudes to learning and sharing individual and organisational knowledge in the hospitality industry. Serv. Ind. J. 2009, 29, 1723-1743. [CrossRef]

37. Mehdikhani, R.; Valmohammadi, C. Strategic collaboration and sustainable supply chain management: The mediating role of internal and external knowledge sharing. J. Enterp. Inf. Manag. 2019, 32, 778-806. [CrossRef]

38. Van den Hooff, B.; De Ridder, J.A. Knowledge sharing in context: The influence of organizational commitment, communication climate and CMC use on knowledge sharing. J. Knowl. Manag. 2004, 8, 117-130. [CrossRef]

39. Wang, Z.; Wang, N.; Liang, H. Knowledge sharing, intellectual capital and firm performance. Manag. Decis. 2014, 52, 230-258. [CrossRef]

40. Yang, J. The impact of knowledge sharing on organizational learning and effectiveness. J. Knowl. Manag. 2007, 11, 83-90. [CrossRef]

41. Dong, Y.; Bartol, K.M.; Zhang, Z.-X.; Li, C. Enhancing employee creativity via individual skill development and team knowledge sharing: Influences of dual-focused transformational leadership: Influences of Dual-Focused TFL on Creativity. J. Organ. Behav. 2017, 38, 439-458. [CrossRef]

42. Zeb, A.; Abdullah, N.H.; Hussain, A.; Safi, A. Authentic leadership, knowledge sharing, and employees' creativity. Manag. Res. Rev. 2019, 43, 669-690. [CrossRef]

43. Arsawan, I.W.E.; Kariati, N.M.; Prayustika, P.A.; Wirga, I.W. Elucidating Knowledge Sharing on Innovative Work Behavior: Multiperspective Analysis. ICORE 2019, 5, 670-686.

44. Hülsheger, U.R.; Anderson, N.; Salgado, J.F. Team-level predictors of innovation at work: A comprehensive meta-analysis spanning three decades of research. J. Appl. Psychol. 2009, 94, 1128-1145. [CrossRef]

45. Liu, Y.; Phillips, J.S. Examining the antecedents of knowledge sharing in facilitating team innovativeness from a multilevel perspective. Int. J. Inf. Manag. 2011, 31, 44-52. [CrossRef]

46. Lin, H. Knowledge sharing and firm innovation capability: An empirical study. Int. J. Manpow. 2007, 28, 315-332. [CrossRef]

47. Radaelli, G.; Lettieri, E.; Mura, M.; Spiller, N. Knowledge Sharing and Innovative Work Behaviour in Healthcare: A Micro-Level Investigation of Direct and Indirect Effects. Creat. Innov. Manag. 2014, 23, 400-414. [CrossRef]

48. Slavin, R.E. Research on cooperative learning and achievement: What we know, what we need to know. Contemp. Educ. Psychol. 1996, 21, 43-69. [CrossRef]

49. Choi, S.B.; Kim, K.; Ullah, S.M.E.; Kang, S.-W. How transformational leadership facilitates innovative behavior of Korean workers: Examining mediating and moderating processes. Pers. Rev. 2016, 45, 459-479. [CrossRef]

50. AlShamsi, O.M.; Ajmal, M.M. Knowledge sharing in technology-intensive manufacturing organizations: Analytic hierarchy process approach. Bus. Process Manag. J. 2019, 25, 802-824. [CrossRef]

51. Yang, Z.; Nguyen, V.T.; Le, P.B. Knowledge sharing serves as a mediator between collaborative culture and innovation capability: An empirical research. J. Bus. Ind. Mark. 2018, 33, 958-969. [CrossRef]

52. Alavi, M.; Kayworth, T.R.; Leidner, D.E. An Empirical Examination of the Influence of Organizational Culture on Knowledge Management Practices. J. Manag. Inf. Syst. 2005, 22, 191-224. [CrossRef]

53. Kumar Jha, J.; Varkkey, B. Are you a cistern or a channel? Exploring factors triggering knowledge-hiding behavior at the workplace: Evidence from the Indian R\&D professionals. J. Knowl. Manag. 2018, 22, 824-849. [CrossRef]

54. Mueller, J. A specific knowledge culture: Cultural antecedents for knowledge sharing between project teams. Eur. Manag. J. 2014, 32, 190-202. [CrossRef]

55. Liao, L.-F. A learning organization perspective on knowledge-sharing behavior and firm innovation. Hum. Syst. Manag. 2006, 25, 227-236.

56. Wah, C.Y.; Menkhoff, T.; Loh, B.; Evers, H.-D. Social Capital and Knowledge Sharing in Knowledge-Based Organizations: An Empirical Study. Int. J. Knowl. Manag. 2007, 3, 29-48. [CrossRef]

57. Lin, F.; Evans, R.D.; Kharel, R.; Williams, R.A. Competitor Intelligence and Product Innovation: The Role of Open-Mindedness and Interfunctional Coordination. IEEE Trans. Eng. Manag. 2019, 1-15. [CrossRef]

58. Le, P.B.; Lei, H.; Le, T.T.; Gong, J.; Ha, A.T. Developing a collaborative culture for radical and incremental innovation: The mediating roles of tacit and explicit knowledge sharing. Chin. Manag. Stud. 2020. Ahead of Print. [CrossRef] 
59. Kablan, A. Dark Factories from an Industry 4.0 Perspective: Its Effects on Cost Accounting and Managerial Accounting. In Digital Business Strategies in Blockchain Ecosystems; Hacioglu, U., Ed.; Contributions to Management Science; Springer: Cham, Switzerland, 2020; pp. 503-518. ISBN 978-3-030-29738-1.

60. Thames, L.; Schaefer, D. Software-defined Cloud Manufacturing for Industry 4.0. Procedia CIRP 2016, 52, 12-17. [CrossRef]

61. Klieštik, T.; Nica, E.; Musa, H.; Poliak, M.; Mihai, E.A. Networked, Smart, and Responsive Devices in Industry 4.0 Manufacturing Systems. Econ. Manag. Financ. Mark. 2020, 15, 23-29. [CrossRef]

62. Lee, R.; Lee, J.-H.; Garrett, T.C. Synergy effects of innovation on firm performance. J. Bus. Res. 2019, 99, 507-515. [CrossRef]

63. Xie, X.; Huo, J.; Zou, H. Green process innovation, green product innovation, and corporate financial performance: A content analysis method. J. Bus. Res. 2019, 101, 697-706. [CrossRef]

64. Bettiol, M.; Capestro, M.; Maria, E.D.; Furlan, A. Impacts of industry 4.0 investments on firm performance: Evidence from Italy; Working Papers 0233; Dipartimento di Scienze Economiche “Marco Fanno": Padova, Italy, 2019.

65. Haseeb, M.; Hussain, H.I.; Ślusarczyk, B.; Jermsittiparsert, K. Industry 4.0: A Solution towards Technology Challenges of Sustainable Business Performance. Soc. Sci. 2019, 8, 154. [CrossRef]

66. Rukundo, J.B. Firm performance and innovation in the developing countries: Evidence from firm-level survey. Corp. Ownersh. Control 2017, 15, 235-245. [CrossRef]

67. Abbas, J.; Zhang, Q.; Hussain, I.; Akram, S.; Afaq, A.; Shad, M.A. Sustainable Innovation in Small Medium Enterprises: The Impact of Knowledge Management on Organizational Innovation through a Mediation Analysis by Using SEM Approach. Sustainability 2020, 12, 2407. [CrossRef]

68. Mariani, M.; Borghi, M. Industry 4.0: A bibliometric review of its managerial intellectual structure and potential evolution in the service industries. Technol. Forecast. Soc. Chang. 2019, 149, 119752. [CrossRef]

69. Kmieciak, R.; Michna, A.; Meczynska, A. Innovativeness, empowerment and IT capability: Evidence from SMEs. Ind. Manag. Data Syst. 2012, 112, 707-728. [CrossRef]

70. Podsakoff, P.M.; MacKenzie, S.B.; Podsakoff, N.P. Sources of Method Bias in Social Science Research and Recommendations on How to Control It. Annu. Rev. Psychol. 2012, 63, 539-569. [CrossRef]

71. Podsakoff, P.M.; MacKenzie, S.B.; Lee, J.-Y.; Podsakoff, N.P. Common method biases in behavioral research: A critical review of the literature and recommended remedies. J. Appl. Psychol. 2003, 88, 879-903. [CrossRef]

72. Saini, R. Linking Knowledge Management and Innovation in SMEs: A Structural Equation Modeling Approach. IUP J. Knowl. Manag. 2015, 13, 45-64.

73. Darroch, J. Developing a measure of knowledge management behaviors and practices. J. Knowl. Manag. 2003, 7, 41-54. [CrossRef]

74. Wang, C.L.; Hult, G.T.M.; Ketchen, D.J.; Ahmed, P.K. Knowledge management orientation, market orientation, and firm performance: An integration and empirical examination. J. Strateg. Mark. 2009, 17, 99-122. [CrossRef]

75. Lonial, S.C.; Carter, R.E. The Impact of Organizational Orientations on Medium and Small Firm Performance: A Resource-Based Perspective. J. Small Bus. Manag. 2015, 53, 94-113. [CrossRef]

76. Nawanir, G. The Effect of Lean Manufacturing on Operations Performance and Business Performance in Manufacturing Companies In Indonesia. Ph.D. Thesis, Universiti Utara, Kuala Lumpur, Malaysia, 2016.

77. Ringle, C.M.; Wende, S.; Becker, J.-M. SmartPLS 3; SmartPLS GmbH: Boenningstedt, Germany, 2015.

78. Hair, J.F.; Risher, J.J.; Sarstedt, M.; Ringle, C.M. When to use and how to report the results of PLS-SEM. Eur. Bus. Rev. 2019, 31, 2-24. [CrossRef]

79. Benitez, J.; Henseler, J.; Castillo, A.; Schuberth, F. How to perform and report an impactful analysis using partial least squares: Guidelines for confirmatory and explanatory IS research. Inf. Manag. 2020, 57, 103168. [CrossRef]

80. Ringle, C.M.; Sarstedt, M.; Mitchell, R.; Gudergan, S.P. Partial least squares structural equation modeling in HRM research. Int. J. Hum. Resour. Manag. 2020, 31, 1617-1643. [CrossRef]

81. Rönkkö, M.; McIntosh, C.N.; Antonakis, J.; Edwards, J.R. Partial least squares path modeling: Time for some serious second thoughts. J. Oper. Manag. 2016, 47-48, 9-27. [CrossRef]

82. Sanchez, G. PLS Path Modeling with R; Trowchez Editions: Berkeley, CA, USA, 2013.

83. Schermelleh-Engel, K.; Moosbrugger, H.; Müller, H. Evaluating the Fit of Structural Equation Models: Tests of Significance and Descriptive Goodness-of-Fit Measures. Methods Psychol. Res. 2003, 8, 23-74. 
84. Baron, R.M.; Kenny, D.A. The moderator-mediator variable distinction in social psychological research: Conceptual, strategic, and statistical considerations. J. Pers. Soc. Psychol. 1986, 51, 1173-1182. [CrossRef]

85. Carrión, G.C.; Nitzl, C.; Roldán, J.L. Mediation Analyses in Partial Least Squares Structural Equation Modeling: Guidelines and Empirical Examples. In Partial Least Squares Path Modeling: Basic Concepts, Methodological Issues and Applications; Latan, H., Noonan, R., Eds.; Springer: Cham, Switzerland, 2017; pp. 173-195. ISBN 978-3-319-64069-3.

86. Nitzl, C.; Roldan, J.L.; Cepeda, G. Mediation analysis in partial least squares path modeling: Helping researchers discuss more sophisticated models. Ind. Manag. Data Syst. 2016, 116, 1849-1864. [CrossRef]

87. Müller, J.M.; Buliga, O.; Voigt, K.-I. Fortune favors the prepared: How SMEs approach business model innovations in Industry 4.0. Technol. Forecast. Soc. Chang. 2018, 132, 2-17. [CrossRef]

88. Cegarra-Navarro, J.G.; Wensley, A.K.P. Congenital learning in the Spanish telecommunication industry. J. Bus. Ventur. 2009, 24, 533-543. [CrossRef]

89. Jansen, J.J.P.; Van Den Bosch, F.A.J.; Volberda, H.W. Exploratory Innovation, Exploitative Innovation, and Performance: Effects of Organizational Antecedents and Environmental Moderators. Manag. Sci. 2006, 52, 1661-1674. [CrossRef]

Publisher's Note: MDPI stays neutral with regard to jurisdictional claims in published maps and institutional affiliations.

(C) 2020 by the authors. Licensee MDPI, Basel, Switzerland. This article is an open access article distributed under the terms and conditions of the Creative Commons Attribution (CC BY) license (http://creativecommons.org/licenses/by/4.0/). 